Фармацевтична технологія, біофармація, гомеопатія

Pharmaceutical technology, biopharmacy, homeopathy

Рекомендована д. фармац. наук, проф. Т. Г. Калинюком

УДК 615.453.6:615.322:615.015.14

\title{
ВИВЧЕННЯ ДОПОМІЖНИХ РЕЧОВИН ДЛЯ СТВОРЕННЯ ОРОМУКОЗАЛЬНИХ ТАБЛЕТОК НА ОСНОВІ СУБСТАНЦІЇ АЛЬТАБОР
}

\author{
(Т. В. Крутських ${ }^{1}$, В. І. Кобилінська², А. С. Шаламай² \\ ${ }^{1}$ Національний фармацевтичний університет, Харків \\ 2ПАТ НВЦ «Борщагівський ХФЗ», Київ
}

Резюме: обрано допоміжні речовини для маскування гірко-в'яжучого смаку субстанції альтабор для виготовлення оромукозальних таблеток.

Ключові слова: альтабор, дубильні речовини, коригенти смаку.

Вступ. Як відомо, вірус грипу потрапляє до організму людини переважно через носоглотку. Тому для лікування цієї хвороби доцільно розробити такі ліки, які б уже на першому етапі атаки вірусу мали змогу протистояти йому. Однією з таких лікарських форм є таблетки для розсмоктування в ротовій порожнині. Оромукозальні таблетки повільно розчиняються в ротовій порожнині та забезпечують місцеву і резорбтивну дію активних інгредієнтів [1].

Субстанція альтабор - сухий екстракт суплідь вільхи сірої та клейкої, що містить поліфенольний комплекс елагових дубильних речовин, володіє вираженою противірусною активністю. Антивірусна активність субстанції полягає в інгібуванні нейрамінідази вірусу грипу (ферменту, який відповідає за здатність вірусного віріону проникати в клітину хазяїна і виходити з неї після розмноження), що може працювати на його знищення вже на першому етапі атаки. До того ж, альтабор має антибактеріальну активність відносно як грам негативних, так і до грампозитивних мікроорганізмів і може застосовуватись при приєднанні бактеріальної інфекції. А інтерфероногенна активність субстанції при її резорбції в організмі буде сприяти індукції інтерферону [2]. Тому для субстанції альтабор оромукозальні таблетки є найбільш оптимальним і доцільним варіантом лікарської форми.

Для таблеток, які розсмоктуються в ротовій порожнині, крім вимог ДФУ, що висуваються для таблеток, є додаткові. Такі, як повне розчинення таблетки, без залишків нерозчинних речовин, приємні емоційні враження при прийманні ліків, а також приємний смак та запах таблеток $[3,4]$.

Смак - складний комплекс відчуттів, зумовлених хімічними, фізико-хімічними властивостя- ми речовини, умовами ії прийому та загальним станом організму. Найбільш прийнятна температура для прояву смакових відчуттів знаходиться в межах $30-35^{\circ} \mathrm{C}$. Більш холодне або гаряче погіршує виникнення та сприйняття смакових відчуттів. Чотири основні групи смаку - кислий, солодкий, солоний та гіркий доповнюються впливом температурних і тактильних рецепторів. Будь-який присмак виникає як сумарне сприйняття на основі смакових, дотикових, температурних і нюхових відчуттів.

До цього часу наукова теорія смаку та запаху не стандартизована, що ускладнює створення об'єктивного методу оцінки сили і характеру відчуттів. Дослідники, які вивчають смакову чутливість із застосуванням об'єктивних фізіологічних процесів (наприклад, різниця в слиновиділенні на кисле, гірке або солоне), запропонували схему чутливого приладу «хімічний ніс», сконструйований також прилад «аналог язика». Однак як найбільш розповсюджені використовуються методи органолептичної оцінки визначення числового індексу смаку, який вказує на кращу маскуючу силу середовища. Метою нашої роботи стали дослідження з вибору допоміжних речовин, які не тільки будуть надавати таблетковій масі необхідних технологічних властивостей, що забезпечують точність дозування, стійкість до роздавлювання, стираність, розпадання і стабільність в процесі зберігання, а й мати приємний смак і запах $[5,6]$.

Методи дослідження. Для обрання допоміжних речовин на етапі вибору наповнювачів та коригентів смаку ми поєднали методи проф. А. І. Тенцової та проф. І. А. Єгорова.

Органолептичний метод оцінки коригентів, запропонований А. І. Тенцовою, оснований на розмежуванні інтенсивності сприйняття почуттів і емоцій при проведенні аналізу. Оцінка

ISSN 2312-0967. Фармацевтичний часопис. 2015. № 1 
Фармацевтична технологія, біофармація, гомеопатія

Pharmaceutical technology, biopharmacy, homeopathy

коригенту проводилась 2 групами осіб (по 20 чоловік) за п'ятибальною системою. Одна 3 них оцінювала смак за виникаючими емоційними враженнями в рамках п'ятибальної системи, а саме: дуже приємний (5), приємний (4), непоганий (3), поганий (2), дуже поганий (1). Друга група проводила оцінку тих самих зразків за основними смаковими відчуттями: негіркий (несолоний, несолодкий, некислий), незначно гіркий (незначно солоний, незначно солодкий, незначно кислий), слабко гіркий (слабко солоний, слабко солодкий, слабко кислий), гіркий (солоний, солодкий, кислий), дуже гіркий (дуже солоний, дуже солодкий, дуже кислий). 3 одержаних даних виводили індекс смаку як середнє арифметичне від усіх показань осіб, які брали участь в експерименті.

Оцінку смаку за методом, що запропонований I. А. Єгоровим, проводили за допомогою літерних та числових індексів за участю 20 дегустаторів. 3 метою вираження даних органолептичної оцінки препарату в більш об'єктивних і порівняльних показниках, запропоновано так названу «формулу смаку». Суть її полягає в тому, що смакові ознаки препарату оцінюються літерними і числовими індексами, які складають «смакову карту», що в подальшому дає можливість записати загальну формулу смаку даного лікарського засобу. Відчуття смаку умовно позначають літерами: К - кислий, О - солодкий, Г гіркий, C - солоний. Але відчуття смаку є багатшими, ніж 4 елементарні відчуття. У комплексному відчутті вони комбінуються 3 дотиковими, температурними і нюховими відчуттями. Для доповнення основного смаку слід ввести зазначення присмаку, наприклад «КО» - кисло-солодкий, «ГС» - гірко-солоний тощо, де перша літера вказує на переваження одного смаку над іншим. Але для оцінки складного смаку вказаних літер недостатньо, тому що смак має багато різних відтінків. Починаючи від порогових (мінімальних концентрацій), які викликають смакові відчутті, до доз, які викликають яскраво виражений смак (наприклад, гірко-солоний смак може стати пекучим, солодкий - нудотним тощо), введені цифрові індекси, які розташовані після основної літери і характеризують ступінь смаку.

Так, наприклад, відтінки смаку - «не гіркий», «не кислий», «не солоний» і «не солодкий» позначені індексом 1, що відповідає смаку очищеної води. Індексом 2 позначені: слабко гіркий, слабко кислий, слабко солоний і слабко солодкий смак. Даний відтінок вказує на ледь відчутий смак і відповідає пороговій концентрації наступних еталонних розчинів: Г2 відповідає 0,0002\% водному розчину хініну гідрохлориду; К2 - 0,02\% водному розчину лимонної кислоти;
С2 - 0,1\% водному розчину натрію хлориду і 02 - 0,38\% розчину сахарози. Індексом 3 позначений гіркий, кислий, солоний і солодкий смак, що відповідає нормальному смаку, до якого людина звикла в повсякденному житті. Він добре відчувається, не викликає негативних емоцій, чітко виражений. Індексом 4 позначений сильний смаковий ефект: дуже гіркий, дуже кислий, дуже солоний, дуже солодкий (нудотний). Вказаний смак перевищує наші поняття про смак насамперед відносно їжі - це пересолений, нудотно-солодкий, пекучий, противний. Такий смак викликає неприємні відчуття в ротовій порожнині. При розробці лікарського препарату, а саме при дослідженні складу, «карта смаку» дозволяє більш раціонально і цілеспрямовано вести пошуки допоміжних речовин.

Субстанція альтабор має гіркий в'яжучий смак та специфічний запах. На етапі попередніх досліджень для маскування гіркого-в'яжучого смаку альтабору ми досліджували цукрову пудру, глюкози моногідрат, фруктозу, сорбіт, маніт, лактозу, пектин яблучний та пектин цитрусовий, які вельми розповсюджені, відносно дешеві, широко застосовуються в фармацевтичній технології, дозволені до медичного застосування та мають відповідні смакові характеристики [7, 8]. Масу таблетки передбачали у кількості 0,5 г, дозу альтабору - 20 мг на 1 таблетку. Таким чином, співвідношення діючої та допоміжної речовини у складі було 1 : 25 відповідно. Для експерименту були виготовлені варіанти складів альтабору з наповнювачами в співвідношенні 4:96 відповідно.

Результати й обговорення. Результати проведених досліджень наведено в таблиці 1.

3 аналізу оцінюваних показників смаку отримали такі результати, а саме, додавання до альтабору цукру і глюкози моногідрату значно підвищує солодкість суміші і зменшує гіркоту під час прийому, але сильніше відчувається гіркота після вживання. Додавання пектину яблучного та цитрусового робить суміш кислою з невеликим присмаком гіркоти. Додавання лактози і фруктози підсолоджує суміш, але не маскує гіркого смаку. Найбільш приємними, солодкуватими з невеликим присмаком гіркоти були зразки 3 манітом та сорбітом, які, до того ж, мали охолоджуючий та освіжаючий присмак. Цукор та глюкоза мають високі глікемічні індекси, що обмежує їх застосування в великих кількостях, і, спираючись на одержані дані, ми відмовились від застосування цих речовин у подальших дослідженнях. Для того, щоб «оптимізувати» солодко-кислий смак суміші, ми розробили ряд зразків поєднавши порівну “солодкі» речовини 3 «кислими», і визначили їх смакові властивості, які наведено в таблиці 2. 
Фармацевтична технологія, біофармація, гомеопатія

Pharmaceutical technology, biopharmacy, homeopathy

Таблиця 1. Визначення смакових властивостей альтабору та його сумішей з допоміжними речовинами

\begin{tabular}{|l|c|c|c|}
\hline \multirow{2}{*}{$\begin{array}{c}\text { Склад сумішей } \\
\text { (4:96) }\end{array}$} & \multicolumn{2}{c|}{ Методика А. І. Тенцової } & $\begin{array}{c}\text { Методика } \\
\text { І. А. Сгорова }\end{array}$ \\
\cline { 2 - 4 } & оцінка основного смаку & оцінка емоційних відчуттів & формула смаку \\
\hline Альтабор & $1,1 \pm 0,1$ & $1,1 \pm 0,1$ & Г4 \\
\hline Альтабор + цукор & $3,8 \pm 0,1$ & $3,5 \pm 0,1$ & О4Г3 \\
\hline Альтабор + глюкози моногідрат & $3,5 \pm 0,2$ & $3,3 \pm 0,2$ & О3Г3 \\
\hline Альтабор + фруктоза & $2,9 \pm 0,2$ & $2,9 \pm 0,2$ & О3Г2 \\
\hline Альтабор + сорбіт & $4,0 \pm 0,1$ & $4,1 \pm 0,1$ & О3Г2 \\
\hline Альтабор + маніт & $3,6 \pm 0,1$ & $3,8 \pm 0,1$ & О3Г3 \\
\hline Альтабор + лактоза & $1,9 \pm 0,2$ & $1,8 \pm 0,2$ & К3Г2 \\
\hline Альтабор + пектин яблучний & $3,7 \pm 0,2$ & $3,6 \pm 0,2$ & К3Г2 \\
\hline Альтабор + пектин цитрусовий & $4,0 \pm 0,1$ & $3,9 \pm 0,1$ & \\
\hline
\end{tabular}

Таблиця 2. Визначення смакових властивостей сумішей альтабору з допоміжними речовинами

\begin{tabular}{|l|c|c|c|}
\hline \multirow{2}{*}{$\begin{array}{c}\text { Склад сумішей } \\
(4: 48: 48)\end{array}$} & \multicolumn{2}{c|}{ Методика А. І. Тенцової } & $\begin{array}{c}\text { Методика } \\
\text { І. А. Сгорова }\end{array}$ \\
\cline { 2 - 4 } & $\begin{array}{c}\text { оцінка основного } \\
\text { смаку }\end{array}$ & $\begin{array}{c}\text { оцінка емоційних } \\
\text { відчуттів }\end{array}$ & формула смаку \\
\hline Альтабор+ лактоза+ пектин яблучний & $2,1 \pm 0,2$ & $2,0 \pm 0,2$ & О2К3Г3 \\
\hline Альтабор + лактоза+ пектин цитрусовий & $2,2 \pm 0,2$ & $2,2 \pm 0,2$ & О2К3Г2 \\
\hline Альтабор + фруктоза+ пектин яблучний & $3,1 \pm 0,2$ & $3,0 \pm 0,2$ & О3К3Г3 \\
\hline Альтабор + фруктоза+ пектин цитрусовий & $3,1 \pm 0,2$ & $3,2 \pm 0,2$ & О3К3Г2 \\
\hline Альтабор + сорбіт+ пектин яблучний & $3,8 \pm 0,2$ & $3,7 \pm 0,2$ & О3К2Г2 \\
\hline Альтабор + сорбіт+ пектин цитрусовий & $4,1 \pm 0,1$ & $4,3 \pm 0,1$ & О3К2Г2 \\
\hline Альтабор + маніт+ пектин яблучний & $3,8 \pm 0,2$ & $3,6 \pm 0,2$ & О3К2Г2 \\
\hline Альтабор + маніт+ пектин цитрусовий & $3,8 \pm 0,1$ & $4,0 \pm 0,1$ & О3К2Г2 \\
\hline
\end{tabular}

За результатами оцінюваних показників смаку визначили, що найбільш прийнятними, «свіжими» були суміші з манітом і сорбітом у поєднанні з цитрусовим пектином, але все одно відчувався в'яжучий смак альтабору. Суміші з лактозою та фруктозою не задовольнили дегустаторів за оцінкою емоційних відчуттів, як і суміші сорбіту і маніту з яблучним пектином. Таким чином, для подальшого вивчення нами було відібрано композиції, які містили сорбіт та маніт з пектином цитрусовим. Ми виготовили низку зразків з альтабором з різним співвідношенням сорбіту, маніту та цитрусового пектину (60:40, 70:30, 80:20, 90:10, 95:5). Частка цитрусового пектину становила менше 50 \%, оскільки попередні зразки мали кислий смак.

3 аналізу оцінюваних показників смаку отримали такі результати, а саме, найбільш прийнятними виявилися зразки сорбіту, маніту з цитрусовим пектином у співвідношенні 80:20 та 90:10 відповідно.

Ці зразки мали солодкувато-кислуватий, охолоджуючий, свіжий смак, однак все одно відчувався в'яжучий смак альтабору, але зразки 3 сорбітом були більш приємні. Тому для подальших досліджень нами було обрано склад суміші із сорбітом і цитрусовим пектином. Крім смакових характеристик, сорбіт також був обраний завдяки своїм властивостям, а саме: сорбіт стабільний, хімічно індиферентний, має добру пластифікуючу здатність та здатність до вологостабілізації, надає таблеткам глянцеву поверхню, широко використовується в різних галузях господарства у всьому світі; за рахунок того, що він має відносно невисокий глікемічний індекс, його можна застосовувати діабетикам та людям з великою масою тіла; сорбіт стійкий до кислот, які утворюються під час метаболізму бактерій у ротовій порожнині, тобто не карієсогенний, що дуже важливо для таблеток для розсмоктування; гарно «працює» з іншими підсолоджувачами з виникненням синергізму між ними; має послаблюючу дію на організм людини, що доцільно враховувати при розробці лікарського засобу із субстанцією на основі елаготанінового комплексу $[7,8]$.

Для видалення в'яжучого смаку діючої речовини ми розробили низку зразків, які містили альтабор, сорбіт, пектин цитрусовий та такі коригенти смаку, як сахарин натрію, ксиліт, аскорбінову та лимонну кислоти в різноманітних співвідношеннях. Альтабор застосовували в кон-

ISSN 2312-0967. Фармацевтичний часопис. 2015. № 1 
Фармацевтична технологія, біофармація, гомеопатія

Pharmaceutical technology, biopharmacy, homeopathy

центрації 4 \%, сорбіт - від 75 до 90 \%, пектин цитрусовий - від 10 до $20 \%$, сахарин натрію або ксиліт - від 0,04 до 0,60\%, аскорбінову або лимонну кислоту - від 0,3 до 2,0 \%. 3 аналізу оцінюваних показників смаку отримали такі результати, а саме, найприйнятніший смак мала суміш, яка містила 4 \% альтабору, 79,45 \% сорбіту, 15 \% пектину цитрусового, 1,5\% лимонної кислоти моногідрату та 0,05\% сахарину натрію. Ця суміш мала солодко-кислуватий, прохолодний, свіжий смак без гіркоти та наявності в'яжучого смаку альтабору. Але всі ці допоміжні речовини не змогли позбавити суміш від специфічного запаху субстанції. Тому нами було прийнято рішення щодо введення до суміші коригенту запаху. Як коригент запаху ми обрали синтетичні порошкоподібні ароматизатори «Ваніль», «Абрикос», «Апельсин» та «Лимон», які додали до суміші в різних концентраціях, а саме, від 0,05 до 0,50 \%. За результатами оцінюваних показників смаку визначили, що такі яскраві ароматизатори, як «Апельсин» та «Лимон» сприяють проявленню в'яжучого смаку альтабору, який ми намагались приховати. Ароматизатор «Ваніль» був сприйнятий позитивно не всіма де-

\section{Література}

1. Технологія ліків промислового виробництва: підручн. в 2-х ч. / В. І. Чуєшов, Є. В. Гладух, І. В. Сайко та ін. - 2-е вид., перероб. і доп. - Х. : НФаУ: Оригінал, 2012. - Ч. 1. - 694 с., - Ч. 2. - 638 с.

2. Крутских Т. В. Таблетки «Альтабор« - новый препарат для лечения вирусных инфекций / Т. В. Крутских, А. С. Шаламай // Фармація України. Погляд у майбутне : матеріали VII Нац. з'їзду фармац. України, м. Харків, 15-17 верес. 2010 р. - Х., 2010. - Т. 1. C. $495-496$.

3. Беляцкая А. В. Особенности технологии изготовления быстрорастворимых гранул и таблеток / А. В. Беляцкая // Фармация. - 2008. - № 3. - С. 35-38. 4. Шевченко А. М. Методологические аспекты разработки технологии твердых быстрорастворимых лекарственных форм : автореф. дис. на соискание учен. степени докт. фарм. наук : спец. 15.00.01 «Технология лекарств и организация фармацевтического дела» / А. М. Шевченко. - Пятигорск, 2009. - 43 с.

5. Шевченко А. М. Выбор состава и фармакологичес- густаторами. А ароматизатор «Абрикос» гарно сприймали всі дегустатори, був дуже «м'який», не сприяв проявленню гіркоти та в'яжучого смаку субстанції, а також не мав неприємного відчуття після вживання суміші.

Висновки. На підставі проведених досліджень із застосуванням методів оцінки коригентів смаку та запаху, розроблених проф. А. І. Тенцовою та проф. І. А. Єгоровим, нами були обрані допоміжні речовини, які повністю маскували гіркий та в'яжучий смак субстанції альтабор і надавали суміші приємного солодкокислуватого, «свіжого», «прохолодного» смаку та аромату. Як основний наповнювач для оромукозальних таблеток 3 альтабором було обрано сорбіт у кількості 79,3 \% від складу суміші, додатковим наповнювачем та коригентом смаку був визначений пектин цитрусовий - $15 \%$, коригентами смаку обрали лимонної кислоти моногідрат у кількості $1,5 \%$ та сахарин натрію - 0,05 \%, як коригент запаху було запропоновано порошкоподібний ароматизатор «Абрикос» у кількості 0,15 \% від складу суміші. При цьому концентрація субстанції альтабор становила $4 \%$.

кое исследование лингвальных таблеток на основе чабреца экстракта жидкого и хлорофиллипта экстракта густого / А. М. Шевченко, Л.В.Гавашелишвили // Курский научно-практический вестник «Человек и его здоровье«. - 2010. - № 4. - С. 135-138.

6. Сучасний стан створення виробництва та дослідження таблетованих лікарських препаратів. Повідомлення 4. Сучасні аспекти створення та виробництва шипучих таблеток / І. І. Басакіна, Д. І. Дмитрієвський, О. В. Тригубчак [та ін.] // Фармацевтичний часопис. 2010. - № 4 (16). - С. 82-86.

7. Допоміжні речовини в технології ліків: вплив на технологічні, споживчі, економічні характеристики і терапевтичну ефективність / [Перцев І. М., Дмитрієвський Д. І., Гудзенко О. П. та ін. ] ; за ред. І. М. Перцева. - Х. : Золоті сторінки, 2010. - 600 с.

8. Вспомогательные вещества для производства твердых лекарственных форм : информ. листок / Витэк груп. - Одесса : Витэк групп. [Электронный ресурс]. - Режим доступа: http://www.witec.com.ua

ISSN 2312-0967. Pharmaceutical review. 2015. № 1 


\section{ИЗУЧЕНИЕ ВСПОМОГАТЕЛЬНЫХ ВЕЩЕСТВ С ЦЕЛЬЮ СОЗДАНИЯ ОРОМУКОЗАЛЬНЫХ ТАБЛЕТОК НА ОСНОВЕ СУБСТАНЦИИ АЛЬТАБОР}

Т. В. Крутских ${ }^{1}$, В. И. Кобылинская², А. С. Шаламай ${ }^{2}$

${ }_{1}$ Национальный фармацевтический университет, Харьков

2ПАО НПЦ «Борщаговский ХФЗ», Киев

Резюме: выбраны вспомогательные вещества с целью маскировки горько-вяжущего вкуса субстанции альтабор для изготовления оромукозальных таблеток.

Ключевые слова: альтабор, дубильные вещества, корригенты вкуса.

\section{STUDY OF EXCIPIENTS FOR CREATION OROMUCOSAL TABLETS BASED ON SUBSTANCE ALTABOR}

\section{T. V. Krutskikh', V. I. Kobylinskaya ${ }^{2}$, A. S. Shalamay ${ }^{2}$}

${ }^{1}$ National Pharmaceutical University, Kharkiv

2JSC SIC «Borshchahivka CPP», Kyiv

Summary: the selected excipients to mask the bitter taste substances altabor for making oromukosal tablets.

Key words: altabor, tannins, flavors taste. 